\title{
ANALISIS KINERJA PT. PLN (PERSERO) AREA BALI UTARA DENGAN MENGGUNAKAN METODE BALANCED SCORECARD TAHUN 2015
}

\author{
Ni Ketut Restiani \\ Jurusan Pendidikan Ekonomi, Fakultas Ekonomi \\ Universitas Pendidikan Ganesha Singaraja, \\ Indonesia \\ e-mail: restiany1211@gmail.com
}

\begin{abstract}
Abstrak
Penelitian ini bertujuan untuk mengetahui kinerja PT. PLN (persero) Area Bali Utara tahun 2015 ditinjau dari perspektif keuangan, perspektif pelanggan, perspektif proses bisnis internal dan perspektif pembelajaran dan pertumbuhan. Jenis penelitian ini merupakan penelitian deskriptif kuantitatif. Data dikumpulkan dengan metode kuisioner dan dokumentasi. Subjek penelitian adalah PT. PLN (persero) Area Bali Utara dan obyek penelitian adalah metode balanced scorecard. Hasil penelitian menunjukkan bahwa Kinerja PT. PLN (persero) Area Bali Utara masih dikatakan dalam kondisi kurang sehat dengan kategori B yang memiliki nilai total keseluruhan yaitu 31,95 yang ditunjukkan skor masing-masing perspektif yaitu, perspektif keuangan memiliki skor sebesar 12 dengan nilai kurang baik, perspektif pelanggan memiliki skor sebesar 4,72 dengan nilai kurang baik, perspektif proses bisnis internal memiliki skor sebesar 6,05 dengan nilai cukup baik, dan perspektif pembelajaran dan pertumbuhan memiliki skor sebesar 4,39 dengan nilai kurang baik.
\end{abstract}

Kata kunci: pengukuran kinerja, balanced scorecard

This research was intended to know the performance of PT. PLN (Persero) North Bali Area 2015 reviewed from a financial perspective, perspective of the customer, perspective of internal business processes and the perspective of learning and growth. The type of this research was quantitative descriptive research. Data was collected by questionnaire and documentation method. Research subject in this research was PT. PLN (Persero) North Bali Area and the object of research was balanced scorecard method. The results showed the performance of PT. PLN (Persero) of North Bali Area was still less healthy with category $B$ which an the overall total value of 31,95 which was experiencing each perspective that is, financial perspective had score 12 with less good value, perspective customers had score of 4,72 with less good value,perspective internal business process perspective had score of 6,05 with good enough value, and perspective of learning and growth had score equal to 4,39 with less good value.

Keywords: performance measurement, balanced scorecard

\section{PENDAHULUAN}

Pengukuran kinerja perusahaan menjadi hal yang sangat penting bagi manajemen untuk melakukan evaluasi terhadap performa perusahaan dan perencanaan tujuan di masa mendatang. Berbagai data diperolah agar pekerjaan yang dilakukan dapat dikendalikan dan dipertanggungjawabkan. $\mathrm{Hal}$ ini dilakukan untuk mencapai efisiensi dan efektivitas pada seluruh proses bisnis perusahaan. Untuk melakukan pengukuran tersebut, diperlukan kemampuan untuk mengukur kinerja sehingga diperlukan adanya ukuran kinerja. Pengukuran kinerja merupakan alat bagi manajemen untuk menilai keberhasilan organisasi (Halim, 2013). Pengukuran kinerja sektor publik 
dilaksanakan untuk menilai pencapaian organisasi melalui alat keuangan dan non keuangan (Halim, 2013). Alat ukur kinerja memuat indikator-indikator kinerja yang menjadi dasar untuk melakukan evaluasi terhadap pencapaian organisasi. Indikator kinerja adalah ukuran kuantitatif dan atau kualitatif yang menggambarkan tingkat pencapaian suatu sasaran atau tujuan yang telah ditetapkan (Bastian, 2005). Oleh karena itu, indikator kinerja harus merupakan sesuatu yang akan dihitung dan diukur serta digunakan sebagai dasar untuk menilai atau melihat tingkat kinerja, baik dalam tahap perencanaan, tahap pelaksanaan, maupun tahap setelah kegiatan selesai. Dengan demikian, tanpa adanya indikator kinerja, sulit bagi kita untuk menilai tingkat keberhasilan dan ketidakberhasilan kebijaksanaan maupun program suatu instansi pemerintah. Dengan indikator kinerja, suatu organisasi mempunyai wahana yang jelas bagaimana dia akan dikatakan berhasil atau tidak berhasil di masa yang akan datang. Tika (2006:121) menjelaskan kinerja adalah hasil-hasil fungsi pekerjaan/ kegiatan seseorang atau kelompok dalam suatu organisasi yang dipengaruhi oleh berbagai faktor untuk mencapai tujuan perusahaan dalam periode waktu tertentu. Menurut Bastian (dalam Tangkilisan, 2005) kinerja adalah gambaran mengenai tingkat pencapaian pelaksanaan tugas dalamsuatu organisasi, dalam upaya mewujudkan sasaran, tujuan, misi, dan visi organisasi tersebut. Sedangkan menurut Mangkunegara (2000:67) kinerja adalah hasil kerja secara kualitas dan kuantitas yang dicapai oleh seseorang pegawai dalam melaksanakan tugasnya sesuai dengan tanggung jawab yang diberikan kepadanya.

Dari pengertian diatas dapat ditarik simpulan bahwa kinerja adalah usaha atau kegiatan yang dilakukan oleh seseorang atau kelompok untuk mewujudkan apa yang diharapkan di suatu organisasi / perusahaan tersebut.
Untuk mengetahui hasil kinerja suatu perusahaan baik atau tidak,maka perlu dilakukan pengukuran kinerja.

Kinerja instansi pemerintah bersifat multidimensional. Dalam arti, tidak ada indikator tunggal yang dapat digunakan untuk menunjukkan tingkat keberhasilan secara komprehensif untuk semua jenis instansi pemerintah. Indikator kinerja yang dipilih akan sangat tergantung pada faktor kritis keberhasilan yang telah diidentifikasi. Menurut Mahsun (2006) terdapat empat pendekatan pengukuran kinerja yang dapat diaplikasikan pada organisasi sektor publik, yaitu: pertama, analisis anggaran; kedua, analisis rasio laporan keuangan; ketiga, balanced scorecard dan keempat, audit kinerja (value for money). balanced scorecard merupakan metode untuk menterjemahkan visi dan strategi ke dalam berbagai tujuan dan mengukur kinerja seseorang atau kelompok/ organisasi dengan menggunakan ukuran kartu untuk mencatat skor hasil -hasil kinerja dalam perangkat perspektif yang seimbang. Menurut Kaplan dan Norton (dalam Tika, 2006) scorecard terdiri dari berbagai ukuran hasil yang diinginkan perusahaan dan juga berbagai proses yang akan mendorong tercapainya hasil masa depan yang diinginkan.

$$
\text { Menurut Halim (2003), }
$$

keunggulan balanced scorecard sebagai metode pengukuran kinerja manajemen yang komprehensif yang berarti balanced scorecard menekankan pengukuran kinerja tidak hanya pada aspek kuantitatif saja, tetapi juga aspek kualitatif dengan memiliki empat perspektif yakni perspektif keuangan, perspektif pelanggan, perspektif proses bisnis internal serta prespektif pembelajaran dan perkembangan. balanced scorecard mengukur sasaran-sasaran strategik yang sulit untuk diukur.

PT. PLN adalah perusahaan Badan Usaha Milik Negara yang ditunjuk oleh pemerintah untuk menyelenggarakan dan mengelola listrik, memiliki tanggung jawab yang 
besar dalam pembangunan, pengelolaan, dan penyediaan tenaga listrik di seluruh wilayah Indonesia. Dalam mengukur kinerja BUMN, pemerintah memiliki standar penilaian yang tertuang dalam Keputusan Menteri No. 100 tahun 2002 tentang Penilaian Tingkat Kesehatan Badan Usaha Milik Negara. Keputusan ini berisi mengenai penilaian tingkat kesehatan BUMN berdasarkan jenisnya yaitu BUMN Infrastruktur dan BUMN Non Infrastruktur. Kesehatan BUMN ditetapkan berdasarkan penilaian terhadap kinerja perusahaan untuk tahun buku yang bersangkutan meliputi penilaian aspek keuangan, aspek operasional dan aspek administrasi (http://www.depkeu.go.id).

PT. PLN (Persero) Area Bali Utara merupakan perusahaan milik Negara yang bergerak di bidang kelistrikan yang mencakup 5 (lima) rayon yaitu rayon Singaraja, Tejakula, Seririt, Negara dan Gilimanuk. PT. PLN (Persero) Area Bali Utara memerlukan system pengendalian manajemen yang dapat menilai kinerja secara akurat dan responsif terhadap perubahan lingkungan, khususnya pelayanan yang prima kepada masyarakat. Salah satu strategi perusahaan guna mencapai visi perusahaan adalah dengan menjalankan bisnis kelistrikan dan bidang lain yang terkait, berorientasi pada kepuasan pelanggan, anggota perusahaan, dan pemegang saham. Hal ini menunjukkan bahwa perusahaan memerlukan suatu pengukuran kinerja yang dapat menerjemahkan visi dan misi perusahaan, tidak hanya dari perspektif keuangan saja, melainkan dari perspektif pelanggan, yang termasuk di sini adalah kecepatan layanan kepada pelanggan dan kecepatan penambahan pelanggan baru atau perluasan wilayah jangkauan listrik; perspektif bisnis internal, termasuk dalam hal ini proses kerja yang tidak berbelit-belit; dan perspektif pertumbuhan dan pembelajaran, termasuk peningkatan kesejahteraan dan kualitas sumber daya manusia di PLN tersebut.
Akan tetapi, pada observasi awal yang penulis lakukan bahwa pengukuran kinerja yang selama ini dilakukan PT. PLN (Persero) Area Bali Utara masih menggunakan pendekatan tradisional yaitu pengukuran kinerja yang bersumber dari informasi keuangan perusahaan saja dengan menggunakan perhitungan SAP (Standar Akuntansi Pemerintahan). Pengukuran kinerja berdasarkan pendekatan tradisional mempunyai kelemahan, antara lain berorientasi pada kepentingan jangka pendek namun tidak berorientasi pada kepentingan jangka panjang. Pengukuran ini tidak dapat mengukur tingkat keberhasilan suatu kinerja yang sesungguhnya. Karena ketidakmampuan organisasi dalam melakukan apa yang harus diambil saat ini dan yang akan datang, untuk meningkatkan kinerja organisasi. Disamping itu, sistem pengukuran kinerja ini dianggap tidak dapat mengukur aset tidak berwujud yang dimiliki organisasi seperti sumber daya manusia, kepuasan pelanggan, loyalitas pelanggan, dan lain sebagainya. Sehingga berbanding terbalik dengan visi dan misi yang diterapkan oleh PT. PLN tersebut. Oleh karena itu, peneliti mencoba untuk mengaplikasikan pengukuran dengan menggunakan metode balanced scorecard, agar didalam pengukuran kinerja tersebut dapat seimbang antara kinerja keuangan dannon keuangan. Kinerja yang dimaksud ditinjau dariperspektif keuangan, perspektif pelanggan, perspektif proses bisnis internal, dan dari pembelajaran dan pertumbuhan.

\section{METODE}

Penelitian ini termasuk dalam jenis penelitian deskriptif kuantitatif. Data yang akan dicari dalam penelitian ini yaitu pengukuran kinerja PT. PLN dengan mengunakan metode balanced scorecard yang meliputi aspek-aspek perspektif yaitu pertama, perspektif keuangan, kedua, perspektif pelanggan, ketiga, perspektif proses bisnis internal, serta keempat, perspektif pertumbuhan dan pembelajaran. Adapun hasil yang 
diharapkan dari penelitian ini dari pengukuran kinerja ini yaitu dari aspek keuangan dan aspek operasional sudah baik atau tidak. Teknik pengumpulan data yang digunakan yaitu kuesioner dan dokumentasi.

Penelitian ini dilaksanakan di kantor PT. PLN (Persero) Area Bali Utara yang beralamat di Jalan Udayana No. 27, Singaraja - Bali, dengan subjek penelitian adalah PT. PLN (persero) Area Bali Utara. Sedangkan objek penelitian adalah metode balanced scorecard.

Instrumen penelitian ini adalah kuisioner yang disebarkan kepada responden (pelanggan dan karyawan). untuk mengumpulkan data di lapangan, kuisioner tersebut terlebih dahulu harus diuji tingkat validitas dan reliabilitasnya. Untuk mengujinya dapat dilakukan dengan menggunakan Kuisioner yang dirancang dengan menggunakan Skala Likert. Skala Likert merupakan jenis skala SPSS versi 16,0 yang digunakan untuk mengukur variabel penelitian (Siregar, 2011). Responden memberikan tanggapan positif dan negatif atau menyatakan persetujuan atau ketidaksetujuan dengan 5 skala angka yaitu selalu (SL), sering kali (SK), kadang-kadang (KK), jarang $(\mathrm{J})$ dan tidak pernah (TP) yang selanjutnya setiap jawaban diberi bobot sebagai berikut dijelaskan pada tabel 1 .

Tabel 1. Pengukuran dengan Model Skala Likert

\begin{tabular}{ccc}
\hline Simbol & Keterangan & Nilai \\
\hline SL & Selalu & 5 \\
SK & Sering Kali & 4 \\
KK & Kadang-Kadang & 3 \\
J & Jarang & 2 \\
TP & Tidak Pernah & 1 \\
\hline
\end{tabular}

(Sumber: Siregar, 2011)

Pertama, Tingkat Kepuasan pelanggan diperoleh dengan total skor dibagi dengan jumlah pelanggan dikali jumlah pertanyaan kemudian hasil keseluruhan dikali $100 \%$ Kedua, Kepuasan karyawan diperoleh dengan total skor dibagi jumlah karyawan dikali jumlah pertanyaan kemudian hasil keseluruhan dikali 100\%. Untuk mengukur Perspektif Keuangan dapat dinilai dari beberapa aspek yaitu:

$$
\text { Pertama, Retun On Equity }
$$

(ROE) dirumuskan dengan laba setelah pajak dibagi modal sendiri kemudian dikali $100 \%$. Rumus ini dapat dijelaskan pada tabel 2 .

Tabel 2. Kriteria Penilaian ROE

\begin{tabular}{ccc}
\hline$R O E(\%)$ & Skor Infrastruktur & Skor Non Infrastruktur \\
\hline $15<\mathrm{ROE}$ & 15 & 20 \\
$13<\mathrm{ROE} \leq 15$ & 13.5 & 18 \\
$11<\mathrm{ROE} \leq 13$ & 12 & 16 \\
$9<\mathrm{ROE} \leq 11$ & 10.5 & 14 \\
$7.9<\mathrm{ROE} \leq 9$ & 9 & 12 \\
$6.6<\mathrm{ROE} \leq 7.9$ & 7.5 & 10 \\
$5.3<\mathrm{ROE} \leq 6.6$ & 6 & 8.5 \\
$4<\mathrm{ROE} \leq 5.3$ & 5 & 7 \\
$2.5<\mathrm{ROE} \leq 4$ & 4 & 5.5 \\
$1<\mathrm{ROE} \leq 2.5$ & 3 & 4 \\
$0<\mathrm{ROE} \leq 1$ & 1.5 & 2 \\
$\mathrm{ROE}<0$ & 1 & 0 \\
\hline
\end{tabular}

(Sumber: Rangkuti, 2011) 
Kedua, Return On Invesment (ROI), menunjukkan efektivitas pemakaian sumberdaya oleh perusahaan, dan dirumuskan dengan laba bersih dbagi total asset kemudian dikali 100\%. rumus ini dapat dijelaskan pada tabel 3 dengan kriteria penilaian $\mathrm{ROI}$ sebagai berikut.

Tabel 3. Kriteria Penilaian $R O I$

\begin{tabular}{lcc}
\hline \multicolumn{1}{c}{$R O I(\%)$} & Skor Infrastruktur & Skor Non Infrastruktur \\
\hline $18<\mathrm{ROI}$ & 10 & 15 \\
$15<\mathrm{ROI} \leq 18$ & 9 & 13.5 \\
$13<\mathrm{ROI} \leq 15$ & 8 & 12 \\
$12<\mathrm{ROI} \leq 13$ & 7 & 10.5 \\
$10.5<\mathrm{ROI} \leq 12$ & 6 & 9 \\
$9<\mathrm{ROI} \leq 10.5$ & 5 & 7.5 \\
$7<\mathrm{ROI} \leq 9$ & 4 & 6 \\
$5<\mathrm{ROI} \leq 7$ & 3.5 & 5 \\
$3<\mathrm{ROI} \leq 5$ & 3 & 4 \\
$1<\mathrm{ROI} \leq 3$ & 2.5 & 3 \\
$0<\mathrm{ROI} \leq 1$ & 2 & 2 \\
$\mathrm{ROI}<0$ & 0 & 1 \\
\hline
\end{tabular}

(Sumber : Rangkuti, 2011)

Ketiga, Current Ratio, digunakan untuk mengukur kemampuan perusahaan untukmenyelesaikan kewajiban jangka pendek dengan mengukur aktiva lancar

dirumuskan dengan current asset dibagi current liabilities dikali $100 \%$. Rumus ini dapat dijelaskan pada tabel 4 .

Tabel 4. Kriteria Penilaian Current Ratio

\begin{tabular}{lcc}
\hline \multicolumn{1}{c}{ Current Ratio (\%) } & Skor Infrastruktur & Skor Non Infrastruktur \\
\hline $125 \leq$ Current Ratio & 3 & 5 \\
$110 \leq$ Current Ratio $<125$ & 2.5 & 4 \\
$100 \leq$ Current Ratio $<110$ & 2 & 3 \\
$95 \leq$ Current Ratio $<100$ & 1.5 & 2 \\
$90 \leq$ Current Ratio $<95$ & 1 & 1 \\
Current Ratio 90 & 0 & 0 \\
\hline
\end{tabular}

(Sumber: Rangkuti, 2011)

Keempat, Colection Periods (CP), digunakan untuk mengukur jumlah ratarata waktu yang diperlukan untuk menagih suatu tagihan, dirumuskan

dengan total piutang usaha dibagi total pendapatan usaha kemudian dikali 365 hari. Berikut dapat disajikan pada tabel 5.

Tabel 5. Kriteria Penilaian Collection Periods

\begin{tabular}{lcc}
\hline \multicolumn{1}{c}{ Collection Periods (Hari) } & Skor Infrastruktur & Skor Non Infrastruktur \\
\hline $\mathrm{CP} \leq 60$ & 4 & 5 \\
$60<\mathrm{CP} \leq 90$ & 3.5 & 4.5 \\
$90<\mathrm{CP} \leq 120$ & 3 & 4 \\
$120<\mathrm{CP} \leq 150$ & 2.5 & 3.5 \\
$150<\mathrm{CP} \leq 180$ & 2 & 3 \\
$180<\mathrm{CP} \leq 210$ & 1.6 & 2.4 \\
$210<\mathrm{CP} \leq 240$ & 1.2 & 1.8 \\
$240<\mathrm{CP} \leq 270$ & 0.8 & 1.2 \\
$270<\mathrm{CP} \leq 300$ & 0.4 & 0.6 \\
$300<\mathrm{CP}$ & 0 & 0 \\
\hline
\end{tabular}

(Sumber: Rangkuti, 2011) 
Kelima, Cash Ratio dirumuskan dengan kas ditambah bank ditambah surat berharga jangka pendek dibagi hutang lancar kemudian dikali 100\%. Berikut ini dapat dijelaskan pada tabel 6 pada kriteria penilaian cash ratio.

Tabel 6. Kriteria Penilaian Cash Ratio

\begin{tabular}{lcc}
\hline Cash Ratio (\%) & Skor Infrastruktur & Skor Non Infrastruktur \\
\hline $\mathrm{CR} \leq 35$ & 3 & 5 \\
$25 \leq \mathrm{CR}<35$ & 2.5 & 4 \\
$15 \leq \mathrm{CR}<25$ & 2 & 3 \\
$10 \leq \mathrm{CR}<15$ & 1.5 & 2 \\
$5 \leq \mathrm{CR}<10$ & 1 & 1 \\
$0 \leq \mathrm{CR}<5$ & 0 & 0 \\
\hline
\end{tabular}

(Sumber: Rangkuti, 2011)

Keenam, Perputaran persediaan dirumuskan dengan total persediaan dibagi total pendapatan dikali 365 hari.
Berikut ini dapat dijelaskan pada tabel 7 dengan kriteria penilaian perputaran persediaan.

Tabel 7. Kriteria Penilaian PP

\begin{tabular}{lcc}
\hline \multicolumn{1}{c}{$P P($ Hari $)$} & Skor Infrastruktur & Skor Non Infrastruktur \\
\hline $\mathrm{PP} \leq 60$ & 4 & 5 \\
$60<\mathrm{PP} \leq 90$ & 3.5 & 4.5 \\
$90<\mathrm{PP} \leq 120$ & 3 & 4 \\
$120<\mathrm{PP} \leq 150$ & 2.5 & 3.5 \\
$150<\mathrm{PP} \leq 180$ & 2 & 3 \\
$180<\mathrm{PP} \leq 210$ & 1.6 & 2.4 \\
$210<\mathrm{PP} \leq 240$ & 1.2 & 1.8 \\
$240<\mathrm{PP} \leq 270$ & 0.8 & 1.2 \\
$270<\mathrm{PP} \leq 300$ & 0.4 & 0.6 \\
$300<\mathrm{PP}$ & 0 & 0 \\
\hline
\end{tabular}

(Sumber : Rangkuti, 2011)

Ketujuh, TATO dirumuskan dengan

total pendapatan dibagi capital

employed dikali 100\%. Berikut ini dapat dijelaskan pada tabel 8.

Tabel 8. Kriteria Penilaian TATO

\begin{tabular}{lcc}
\hline TATO $(\%)$ & Skor Infrastruktur & Skor Non Infrastruktur \\
\hline $120 \leq$ TATO & 4 & 5 \\
$105<$ TATO $\leq 120$ & 3.5 & 4.5 \\
$90<$ TATO $\leq 105$ & 3 & 4 \\
$75<$ TATO $\leq 90$ & 2.5 & 3.5 \\
$60<$ TATO $\leq 75$ & 2 & 3 \\
$40<$ TATO $\leq 60$ & 1.5 & 2.5 \\
$20<$ TATO $\leq 40$ & 1 & 2 \\
TATO $\leq 20$ & 0.5 & 1.5 \\
\hline
\end{tabular}

(Sumber: Rangkuti, 2011)

Kedelapan, TMS Terhadap TA dirumuskan dengan total modal sendiri dibagi total asset kemudian hasil dari pembagian tersebut mendapatkan total skor yang akan dikali 100\%. Berikut ini dapat dijelaskn pada tabel 9 dengan kriteria penilaian Total Modal Sendiri terhadap Total Asset. 
Tabel 9. Kriteria Penilaian TMS Terhadap TA

\begin{tabular}{lcc}
\hline \multicolumn{1}{c}{ Perputaran Total Asset $(\%)$} & Skor Infrastruktur & Skor Non Infrastruktur \\
\hline TMS terhadapTA $<0$ & 0 & 0 \\
$0 \leq$ TMS terhadap TA $<10$ & 2 & 4 \\
$10 \leq$ TMS terhadap TA $<20$ & 3 & 6 \\
$20 \leq$ TMS terhadap TA $<30$ & 4 & 7.25 \\
$30 \leq$ TMS terhadap TA $<40$ & 6 & 10 \\
$40 \leq$ TMS terhadap TA $<50$ & 5.5 & 9 \\
$50 \leq$ TMS terhadap TA $<60$ & 5 & 8.5 \\
$60 \leq$ TMS terhadap TA $<70$ & 4.5 & 8 \\
$70 \leq$ TMS terhadap TA $<80$ & 4.25 & 7.5 \\
$80 \leq$ TMS terhadap TA $<90$ & 4 & 7 \\
$90 \leq$ TMS terhadap TA $<100$ & 3.5 & 6.5 \\
\hline
\end{tabular}

(Sumber : Rangkuti, 2011)

Untuk mengukur aspek operasional yang meliputi perspektif pelanggan, perspektif proses bisnis internal, dan perspektif pembelajaran dan pertumbuhan dapat dilakukan dengan pertama, mengukur tingkat retensi pelanggan dirumuskan dengan jumlah pelanggan lama dibagi jumlah pelanggan dikali $100 \%$.

Kedua, akuisisi pelanggan dirumuskan dengan jumlah pelanggan baru dibagi jumlah pelanggan dikali $100 \%$ dan ketiga, tingkat kepuasan pelanggan dirumuskan dengan total skor dibagi dengan jumlah pelanggan dikali jumlah pertanyaan kemudian hasil keseluruhan dikali 100\%.

Proses operasional yang berupa susut distribusi dirumuskan dengan Kwh siap salur ke distribusi dikurangi Kwh penjualan kemudian dibagi Kwh siap salur ke distribusi kemudian dikali $100 \%$. Mengukur tingkat kepuasan karyawan dirumuskan dengan total skor dibagi jumlah karyawan dikali jumlah pertanyaan kemudian dikali $100 \%$ dan restensi karyawan dirumuskan dengan total skor dibagi jumlah karyawan kemudian hasil dari pembagian tersebut dibagi jumlah pertanyaan dikali $100 \%$.

Penilaian terhadap masingmasing indikator atau aspek dilakukan secara kualitatif dengan kategori penilaian dan penetapan berdasarkan SK Menteri BUMN No. 100/MBU/2002. Berikut ini dapat dijelaskan pada tabel 10 dengan daftar indikator dan bobot aspek keuangan yang terdiri dari ROE, ROI, Current Ratio, Collection Period, Cash Ratio, Perputaran Persediaan, TATO, dan TMS terhadap Total Asset

Tabel 10. Daftar indikator dan bobot aspek keuangan

\begin{tabular}{lcc}
\hline \multicolumn{1}{c}{ Indikator } & \multicolumn{1}{c}{ Bobot } \\
\cline { 2 - 3 } \cline { 2 - 3 } 1. ROE & Infrastruktur & Non infrastruktur \\
2. ROI & 15 & 20 \\
3. Current Ratio & 10 & 15 \\
4. Collection Period & 4 & 5 \\
5. Cash Ratio & 4 & 5 \\
6. PP & 3 & 5 \\
7. TATO & 4 & 5 \\
8. TMS terhadap TA & 4 & 5 \\
\hline Jumlah & 6 & 10 \\
\hline
\end{tabular}

(Sumber: Keputusan Menteri BUMN No: Kep 100/MBU/2002)

Penilaian daftar indikator dan bobot operasional yang terdiri dari retensi pelanggan, akuisisi pelanggan, kepuasan pelanggan, retensi dan kepuasan karyawan serta susut distribusi. Hal tersebut dapat dijelaskan dengan tabel 11 yang bersumber dari keputusan menteri BUMN No: Kep 100/MBU/2002 sebagai berikut. 
Tabel 11. Daftar indikator dan bobot aspek operasional

\begin{tabular}{lll}
\hline \multicolumn{1}{c}{ Indikator } & \multicolumn{2}{c}{ Bobot } \\
\cline { 2 - 3 } & Infrastruktur & Non infrastruktur \\
\hline 1. $\begin{array}{l}\text { Retensi pelanggan, } \\
\text { Akuisisi Pelanggan dan } \\
\text { Kepuasan Pelanggan }\end{array}$ & 15 & 5 \\
\hline $\begin{array}{l}\text { 2. Retensi dan Kepuasan } \\
\text { Karyawan }\end{array}$ & 10 & 5 \\
\hline 3. Susut Distribusi (Losses) & 10 & 5 \\
\hline Jumlah & $\mathbf{3 5}$ & $\mathbf{1 5}$ \\
\hline
\end{tabular}

(Sumber: Keputusan Menteri BUMN No: Kep 100/MBU/2002)

Menurut Rangkuti (2011),

Penilaian terhadap masing-masing indikator dilakukan secara kualitatif dengan kategori penilaian dan penetapan skornya yaitu Baik Sekali (BS): skor $=100 \%$ dikali bobot indikator yang bersangkutan, Baik (B) : skor = $80 \%$ dikali bobot indikator yang bersangkutan, Cukup $(\mathrm{C})$ : skor $=50 \%$ dikali bobot indikator yang bersangkutan dan Kurang $(\mathrm{K})$ : skor = $20 \%$ dikali bobot indikator yang bersangkutan.

Penilaian kinerja balanced scorecard berdasarkan Keputusan
Menteri No: KEP-100/MBU/2002 pada penelitian ini hanya terkait pada pengukuran kinerja keuangan dan kinerja operasional dengan beberapa unsur penilaian yang telah diukur. Penilaian ini dirumuskan dalam beberapa tahap yaitu Tahap pertama, Menjumlahkan Total skor pada aspek keuangan dengan Total skor pada aspek operasional, Tahap kedua, Mencari hasil dari perhitungan balanced scorecard, dan Tahap ketiga, Menggunakan Kriteria Standar. Penilaian kinerja balanced scorecard dijelaskan pada tabel 12.

Tabel 12. Penilaian kinerja balanced scorecard

\begin{tabular}{lcc}
\hline \multicolumn{1}{c}{ Kondisi } & Kategori & Total Score $(\%)$ \\
\hline Sangat Sehat & AAA & $\geq 95$ \\
& AA & $80<\mathrm{TS}<95$ \\
& A & $65<\mathrm{TS}<80$ \\
Kurang Sehat & BBB & $50<\mathrm{TS}<65$ \\
& BB & $40<\mathrm{TS}<50$ \\
& B & $30<\mathrm{TS}<40$ \\
Tidak Sehat & CCC & $20<\mathrm{TS}<30$ \\
& CC & $10<\mathrm{TS} 20$ \\
& C & TS $<10$ \\
\hline
\end{tabular}

(Sumber : Rangkuti, 2011)

\section{HASIL DAN PEMBAHASAN Hasil}

Penilaian Kinerja Keuangan PT. PLN (Persero) Area Bali Utara berdasarkan Keputusan Menteri BUMN Nomor:Kep-100/MBU/2002 tentang penilaian tingkat kesehatan Badan Usaha Milik Negara. Berikut ini dapat dijelaskan pada tabel 13 yang terdapat penilaian aspek keuangan dengan indikator ROE, ROI, Current Ratio, Collection Period, Cash Ratio, Perputaran Persediaan, TATO, dan Total Modal Sendiri terhadap Total Asset kemudian direliasikan berdasarkan bobot infrastruktur dengan memperoleh total keseluruhan sebesar 50 dengan skor nilai kurang baik. 
Tabel 13. Daftar Penilaian Aspek Keuangan

\begin{tabular}{|c|c|c|c|c|}
\hline \multirow[t]{2}{*}{ No } & \multirow[t]{2}{*}{ Indikator } & \multirow{2}{*}{$\begin{array}{c}\text { Realisasi } \\
2015\end{array}$} & \multirow{2}{*}{$\begin{array}{c}\text { Bobot } \\
\text { Infrastruktur }\end{array}$} & \multirow{2}{*}{$\begin{array}{l}\text { Skor } \\
2015 \\
\end{array}$} \\
\hline & & & & \\
\hline 1 & ROE & $-140 \%$ & 15 & 1 \\
\hline 2 & ROI & $-24 \%$ & 10 & 0 \\
\hline 3 & Current Ratio & $112 \%$ & 4 & 2,5 \\
\hline 4 & Collection Period & 22 hari & 4 & 4 \\
\hline 5 & Cash Ratio & $0 \%$ & 3 & 0 \\
\hline 6 & Perputaran Persediaan & 13.2 hari & 4 & 4 \\
\hline 7 & Total Asset Turn Over & $-343 \%$ & 4 & 0,5 \\
\hline \multirow[t]{3}{*}{8} & Total Modal Sendiri Terhadap Total Asset & $17 \%$ & 6 & 3 \\
\hline & Total Skor & & 50 & 12 \\
\hline & Nilai & & & $\mathrm{K}$ \\
\hline \multicolumn{2}{|c|}{$\begin{array}{l}\text { Penilaian aspek operasional yang } \\
\text { terdiri dari tiga perspektif penilaian yaitu } \\
\text { perspektif pelanggan, perspektif bisnis } \\
\text { internal dan perspektif pembelajaran }\end{array}$} & $\begin{array}{l}\text { dan } \\
\text { opera } \\
\text { mente } \\
\text { beriku }\end{array}$ & $\begin{array}{l}\text { umbuhan. } \\
\text { al berdasa } \\
0.100 \text { Tahu }\end{array}$ & $\begin{array}{l}\text { ian aspek } \\
\text { keputusan } \\
2 \text { sebagai }\end{array}$ \\
\hline
\end{tabular}

Tabel 14. Daftar Penilaian Aspek Operasional

\begin{tabular}{|c|c|c|c|}
\hline & Bobot & Unsur yang dipertimbangkan & Skor \\
\hline Indikator & & & 2015 Nilai \\
\hline Perspektif Pelanggan & 15 & $\begin{array}{l}\text { Retensi Pelanggan, Akuisisi } \\
\text { Pelanggan, Kepuasan Pelanggan }\end{array}$ & 4,72 \\
\hline $\begin{array}{l}\text { Proses Operasional } \\
\text { Perspektif Pembelajaran dan } \\
\text { Pertumbuhan }\end{array}$ & $\begin{array}{l}10 \\
10 \\
\end{array}$ & $\begin{array}{l}\text { Susut Distribusi (Losses) } \\
\text { Kepuasan Karyawan, } \\
\text { Karyawan dan Pelatihan }\end{array}$ & $\begin{array}{ll}6,05 & \mathrm{C} \\
4,39 & \mathrm{~K} \\
\end{array}$ \\
\hline $\begin{array}{c}\text { Total } \\
\end{array}$ & 35 & & 15,16 \\
\hline $\begin{array}{l}\text { Penilaian kinerja ba } \\
\text { scorecard berdasarkan Kep } \\
\text { Menteri No: KEP-100/MBU/2002 } \\
\text { penelitian ini hanya terkait } \\
\text { pengukuran kinerja keuangan } \\
\text { kinerja operasional dengan bel } \\
\text { unsur penilaian yang telah } \\
\text { penilaian ini dirumuskan sebagai } \\
\text { pertama, Menjumlahkan Total } \\
\text { pada aspek keuangan dengan } \\
\text { skor pada aspek operasional. } \\
\text { Tahun } 2015=\text { total skor } \\
\text { keuangan ditambah total skor }\end{array}$ & $\begin{array}{l}\text { nced } \\
\text { usan } \\
\text { pada } \\
\text { pada } \\
\text { dan } \\
\text { rapa } \\
\text { ukur. } \\
\text { ahap } \\
\text { skor } \\
\text { Total } \\
\text { spek } \\
\text { spek }\end{array}$ & $\begin{array}{l}\text { operasional = } 12 \text { ditaml } \\
\text { dengan } 27,16 \text {. Tahap } \\
\text { hasil dari perhitun } \\
\text { scorecard. Penilaian } \\
\text { pada aspek keuanga } \\
\text { operasional sehingga } \\
\text { seharusnya } 100 \text { men } \\
\text { perhitungannya sebagai } \\
\text { Tahun } 2015=27,16 \text { dika } \\
\begin{array}{l}\text { Tahap ketiga. Mengg } \\
\text { Standar balanced }\end{array}\end{array}$ & $\begin{array}{l}\text { Dah } 15.16 \text { sama } \\
\text { kedua, Mencari } \\
\text { yan balanced } \\
\text { anya dilakukan } \\
\text { n dan aspek } \\
\text { otal skor yang } \\
\text { adi } 85 \text {, maka } \\
\text { berikut: } \\
\text { li } \frac{100}{85} \\
\text { Inakan Kriteria } \\
\text { scorecard. }\end{array}$ \\
\hline Tabel. 1 & eria S & indar balanced scorecard & \\
\hline Kondisi & Kategori & Total Score & \\
\hline Sangat Sehat & & $\begin{array}{l}\geq 95 \\
80<\text { TS }<95 \\
65<\text { TS }<80\end{array}$ & \\
\hline Kurang Sehat & & $\begin{array}{l}50<\mathrm{TS}<65 \\
40<\mathrm{TS}<50 \\
30<\mathrm{TS}<40\end{array}$ & \\
\hline $\begin{array}{l}\mathrm{CCC} \\
\mathrm{CC} \\
\mathrm{C}\end{array}$ & & $\begin{array}{l}20<\text { TS }<30 \\
10<\text { TS } 20 \\
\text { TS }<10\end{array}$ & \\
\hline
\end{tabular}


Kesimpulan yang diperoleh adalah perusahaan dengan nilai Total Score 31,95 termasuk dalam kondisi Kurang Sehat dengan kategori B.

\section{Pembahasan}

Berdasarkan hasil penelitian menunjukkan bahwa kinerja PT. PLN (Persero) Area Bali Utara dengan menggunakan metode balanced scorecard menurut Bastian (2005) memiliki empat perspektif yang dinilai yaitu (a). perspektif keuangan, (b). perspektif pelanggan, (c). perspektif proses bisnis internal dan (d) perspektif proses pembelajaran dan pertumbuhan. Dengan demikian untuk melihat hasil analisis kinerja PT. PLN (persero) area bali utara dapat dilihat dari perspektif keuangan dengan memperoleh hasil sebesar 12 dan dilihat dari aspek operasional yang terdiri dari perspektif pelanggan, proses bisnis internal serta perspektif pembelajaran dan pertumbuhan memperoleh hasil sebesar 15,16 dengan satu indikator bernilai cukup dan dua indikator bernilai kurang. Hasil penelitian ini sejalan dengan Keputusan Menteri No: KEP-

\section{SIMPULAN DAN SARAN Simpulan}

Berdasarkan hasil analisis data dan pembahasan, maka dapat ditarik simpulan bahwa Pengukuran kinerja menggunakan metode balanced scorecard memberikan hasil pengukuran yang lebih meluas, dibandingkan pengukuran secara tradisional yang biasanya dilakukan. Karena pengukuran menggunakan metode balanced scorecard mencakup empat perspektif pengukuran yaitu perspektif keuangan, perspektif pelanggan, perspektif bisnis internal dan perspektif pembelajaran dan pertumbuhan yang ada di dalam perusahaan.

Hasil pengukuran balanced scorecard berdasarkan Keputusan Menteri Nomor: Kep-100/MBU/2002 maka PT. PLN (Persero) Area Bali Utara merupakan perusahaan BUMN yang Kurang Sehat dengan kategori B.
100/MBU/2002 tentang Penilaian Tingkat Kesehatan Badan Usaha Milik Negara, dibagi dalam tiga aspek yaitu aspek keuangan, aspek operasional dan aspek administrasi. Akan tetapi penelitian ini menggunakan metode balanced scorecard hanya digunakan dua aspek dari yaitu aspek keuangan dan aspek operasional saja.

Hasil perhitungan dari keempat perspektif balanced scorecard berdasarkan eputusan menteri No: KEP-100/MBU/2002 menunjukkan bahwa secara umum kinerja PT. PLN (Persero) Area Bali Utara berada dalam kondisi kurang sehat dengan kategori $\mathrm{B}$ yang ditunjukkan nilai sebesar 31,95. Hal ini disebabkan karena ada salah satu minimnya hasil yang di peroleh aspek keuangan yaitu pada indikator Return On Equity (ROE), Return On Invesment (ROI), Cash Ratio dan Total Asset Turn Over serta dari aspek operasional yaitu pada perspektif pelanggan yang terdapat pada akuisisi pelanggan memiliki hasil yang rendah dan pada perspektif pembelajaran dan pertumbuhan yaitu pada indikator pelatihan.

Skor yang diperoleh pada tahun 2015 sebesar 31,95.

\section{Saran}

Berdasarkan simpulan yang diperoleh dari hasil penelitian ini, maka dapat dikemukakan saran-saran bagi Perusahaan PT. PLN (Persero) Area Bali Utara, untuk Kinerja Keuangan dapat ditingkatkan lagi dengan mengevaluasi indikator-indikator kinerja yang mengalami penurunanskor indikator yaitu pada indikator Return On Equity (ROE), Return On Invesment (ROI), Cash Ratio dan Total Asset Turn Over serta dari aspek operasional yaitu pada perspektif pelanggan yaitu pada akuisisi pelanggan memiliki hasil yang rendah dan pada perspektif pembelajaran dan pertumbuhan yaitu pada indikator pelatihan mungkin dengan melakukan kegiatan selain diklat.

Bagi peneliti lain yang berminat untuk mendalami mengenai analisis 


\begin{abstract}
kinerja perusahaan dengan menggunakan metode balanced scorecard diharapkan melakukan penelitian lebih lanjut. Hal ini berguna untuk membandingkan antara analisis kinerja secara tradisioanal yaitu menggunakan aspek keuangan saja dengan analisis metode balanced scorecard pada perusahaan satu dengan perusahaan lainnya.
\end{abstract}

\title{
DAFTAR PUSTAKA
}

Bastian, Indra. 2005. Akuntansi Sektor Publik: Suatu Pengantar. Yogyakarta: Erlangga.

Halim, Abdul. dkk. 2003. Sistem Pengendalian Manajemen. Yogyakarta: Akademi Manajemen Perusahaan YKPN 2013. Teori, Konsep, Aplikasi Akuntansi Sektor Publik. Jakarta: Salemba Empat.

Keputusan Menteri BUMN No:Kep100/MBU/2002. Penilaian Tingkat Kesehatan BUMN Non Jasa Keuangan. Diakses pada tanggal 4 desember 2016 dari http://www.depkeu.go.id

Mahsun, Mohamad. 2006. Pengukuran Kinerja Sektor Publik. Yogyakarta: BPFE.

Mangkunegara, Prabu Anwar. 2000. Manajemen Sumber Daya Perusahaan. Bandung: PT. Remaja Rosdakarya.

Tangkilisan, Hessel Nogi S. 2005. Manajemen Publik. Jakarta: PT Grasindo.

Tika, Mohammad Pabundu. 2006. Budaya Organisasi dan Peningkatan Kinerja Perusahaan. Jakarta: PT. Bumi Aksara.

Rangkuti, Freddy. 2011. Swot balanced scorecard. Jakarta: PT.

Gramedia Pustaka Utama. Siregar, Syofian. 2011. Statistika Deskriptif untuk Penelitian. Jakarta: Rajawali Pers. 